\title{
Shame and the temporality of social life
}

\author{
Lisa Guenther
}

(C) Springer Science+Business Media B.V. 2011

\begin{abstract}
Shame is notoriously ambivalent. On one hand, it operates as a mechanism of normalization and social exclusion, installing or reinforcing patterns of silence and invisibility; on the other hand, the capacity for shame may be indispensible for ethical life insofar as it attests to the subject's constitutive relationality and its openness to the provocation of others. Sartre, Levinas and Beauvoir each offer phenomenological analyses of shame in which its basic structure emerges as a feeling of being exposed to others and bound to one's own identity. For Sartre, shame is an ontological provocation, constitutive of subjectivity as a being-for-Others. For Levinas, ontological shame takes the form of an inability to escape one's own relation to being; this predicament is altered by the ethical provocation of an Other who puts my freedom in question and commands me to justify myself. For Beauvoir, shame is an effect of oppression, both for the woman whose embodied existence is marked as shameful, and for the beneficiary of colonial domination who feels ashamed of her privilege. For each thinker, shame articulates the temporality of social life in both its promise and its danger.
\end{abstract}

Keywords Shame $\cdot$ Levinas $\cdot$ Beauvoir $\cdot$ Sartre $\cdot$ Intersubjectivity $\cdot$ Time

Shame is notoriously ambivalent. On one hand, it operates as a mechanism of normalization and social exclusion, installing or reinforcing patterns of silence and invisibility in ways that many feminists, queer theorists, and scholars of race and class have analyzed and critiqued. ${ }^{1}$ The burning feeling of shame, the sense of being

\footnotetext{
1 See, for example, Warner (1999) on queer shame; Fanon (1968) and DuBois (1995) on racial shame; Felski (2000) and Skeggs (1997) on (gendered) class shame.

L. Guenther $(\bowtie)$

Department of Philosophy, Vanderbilt University, 229 Furman Hall, Nashville, TN 37240, USA

e-mail: lisa.n.guenther@gmail.com
} 
out of place, judged by others as unworthy, unwanted or wrong-not only in this or that particular action but in one's very existence-leaves the shameful subject nowhere to be, and yet nowhere to hide or escape. Deprived of supportive relationships to others, I am not merely left to my own devices as an individual, but I find my own agency and integrity undermined by this exclusion. In this sense, shame attacks the very resources that one would need in order to resist shame, and to put in question the mechanisms that produce it and distribute it unevenly among subjects. The trouble with shame is that, when it really takes hold of me, I cannot even stand myself; it is as if my own subjectivity has been replaced by the shame that sticks to it. Kafka, the great poet of shame, puts it this way at the end of The Trial: "it was as if the shame would outlive him."2 A man who has been arrested without reason, accused and convicted of unnamed crimes, tortured and executeda man who has done nothing wrong, and has meekly cooperated in his own destruction-is replaced, in the end, by a shame that outlasts him. This is the misery of shame: both its lack of foundation (Why me? What have I done to deserve this?) and also its capacity to undermine the foundations of the subject (What is left of me? Was there ever a "me" without shame?).

On the other hand, a world without shame may not be possible, or even desirable. While shame is clearly destructive in many ways and many contexts, the capacity for shame has been reevaluated in recent years by social theorists and philosophers who argue that it may be important for relational subject formation. For example, Eve Kosofsky Sedgwick draws on the work of psychologist Silvan Tompkins to argue that shame is not merely a painful feeling of social exclusion, but a primary affect of intersubjective life. The other side of shame is interest; we feel shame because we others matter to us in ways that are constitutive of who we are. While interest is diminished in experiences of shame, this diminishment is part of a continuum that still attests to its other side and remains open to greater and lesser degrees of interest. In this sense, shame may even function as a protective defense against the contingencies of social life, where interest is never guaranteed and may be abruptly withdrawn, even where it is most vital to the self. For Sedgwick, shame is not merely a symptom of this withdrawal, but part of a mechanism for negotiating the vagaries of social life, where others are both necessary and unreliable supports for the self. As such, shame is not to be avoided but rather explored as part of the process of becoming a subject in relation to others, a process which affirms both the pleasures and the risks of social life. ${ }^{3}$

In what follows, I explore this ambivalent process of inter-subjectification through a reading of three phenomenological accounts of shame from Sartre, Levinas and Beauvoir. Each of these thinkers highlight, in different ways, the intersubjective structure of shame as a feeling of being exposed to the gaze of others in a way that makes one feel the desire to escape or disappear, but also the impossibility of doing so. For Sartre, shame attests to a dimension of my own existence that does not originate in self-consciousness, but in my exposure to Others. I call this an ontological account of shame because it speaks to the structure

\footnotetext{
2 Kafka (2000, p. 178).

3 Sedgwick (2003, pp. 35-65, 93-122). For positive, but critical re-appraisals of shame, see Calhoun (2004), Probyn (2005), Bond Stockton (2006), Shotwell (2007), and Tarnopolsky (2010).
} 
of intersubjective being rather than to a particular configuration of historical social relations. Levinas gives a rather different ontological account of shame in his early work, On Escape, followed by an ethical account of shame in Totality and Infinity. In the latter work, shame is figured as a moment of ethical provocation that pulls the subject out of herself and commands her to invest her freedom as responsibility for the Other. In this sense, shame is not the opposite of what Sedgwick calls "interest" or connection to others, but rather an intensification of this connection, to the point where the subject emerges as a radical being-for-Others. But this being-for-Others is not without its political complications. Simone de Beauvoir explores the painful side of the subject's exposure to others in The Second Sex, where a politicized aspect of one's existence-in this case, sexual difference-is marked as inherently shameful and incompatible with free subjectivity. In this sense, she situates the ontological account of shame given by Sartre and the early Levinas within a specific political organization of being in which shame is distributed unevenly among different subjects, privileging some and putting others in precarious, or even impossible, positions. In her later memoir, Force of Circumstance, Beauvoir offers another account of shame from the perspective of one who is privileged by colonial distributions of power, but whose privilege is put in question by others who are exposed to colonial violence in the Algerian war. As such, Beauvoir offers a concrete political elaboration of both ethical shame and ontological shame; her work allows us to see both the ambivalence of shame in excluding and relating to others, but also the ambivalence of any given social position, which may be privileged in some respects and precarious in others.

Each of these phenomenological accounts highlights the ambivalence of shame, in consonance with current discussions of shame in philosophy and social theory. But they also offer a distinctive insight into the temporality of social life in its ontological, ethical and political dimensions. Shame makes me feel frozen in time, stuck to a moment that goes nowhere, opens onto no future, gives me no possibility of becoming otherwise. But shame can also pull me out of myself, disrupting the complacency and self-satisfaction of the same, orienting me in ethical and political solidarity with others, and opening a relation to the future beyond what I could have imagined or constructed as a solitary individual. A phenomenological analysis of the temporality of shame suggests that time itself is relational, that it is neither objective nor subjective but intersubjective. There is no meaningful relation to time without a meaningful relation to others who provoke me in ontological, ethical and political ways, both threatening my access to an open future and-precisely in their capacity to do soattesting to the sense in which time itself is opened up in relation to another.

\section{Shame as ontological provocation}

What is it like to feel shame? The classic phenomenological analysis comes from Sartre's Being and Nothingness. I am crouched at a keyhole, driven by an unsavory motive to position myself as a pure spectator, seeing without being seen. Suddenly, I hear footsteps behind me in the hallway, and I feel myself exposed to the gaze of another. It matters little if this Other is empirically there or not; the feeling of 
exposure introduces something irrevocable into my existence: a being-for-Others that contests my position at the center of the world and adds a new dimension to my existence as a consciousness for-itself. Suddenly, I have an outside, an appearance which is mine, but which nevertheless escapes my own grasp, a skin which is more immediately accessible to others than to myself. The gaze of the Other does not offer me anything in particular to know; rather, it alters my being, triangulating the structure of my existence into a relation between me, myself and the Other. Sartre articulates this triangular structure as follows: "I am ashamed of myself before the Other." 4 This self of which I am ashamed does not already exist prior to the encounter with the Other; rather, it is conferred upon me by the Other's gaze. ${ }^{5}$ From my own perspective as an absolutely free and self-transcending consciousness, "I am what I am not, and I am not what I am." I never coincide with any particular determination of myself. But from the perspective of another free subject who captures me as an object in his or her field of vision, I acquire a "nature," a being that is what it is. ${ }^{7}$ For the Other, but never for myself, "I am somebody," a being who is spatially and temporally positioned within the world. ${ }^{8}$

For Sartre, the subject's deepest desire is to become like God: a being who exists in-and-for-itself, reconciling the split between subject and object. In shame, however, the subject experiences an "original fall," a "feeling of being finally what I am but elsewhere, over there for the Other." 9 At the very moment when I finally coincide with myself, the locus of my being is displaced and alienated from me. In shame, I am expelled from the paradise of a purely subjective freedom. While my own freedom does not disappear, it is now encumbered by the existence of Others who challenge my freedom with their own. "I am no longer master of the situation. Or more exactly, I remain master of it, but it has one real dimension by which it escapes me, by which unforeseen reversals cause it to be otherwise than it appears to me." 10 This "one real dimension" is the presence of another subject. Even as I lose something in shame, I also gain something: an escape from the problem of solipsism, an ontological proof of the existence of the Other. Sartre argues that the feeling of shame could only be produced in me by another free subject, because only another subject is capable of regarding me as an object. ${ }^{11}$ Two absolute freedoms are not compatible with one another; my freedom blocks awareness of the freedom of the Other, since he becomes merely an object in the world of which I am the sole source of value, and my shame reveals the existence of an Other whose freedom reduces me to a mere object in his world. For Sartre, then, shame is not just one emotion among others; it is the fundamental mood of intersubjectivity, just as anguish is the fundamental mood of freedom. I may assert my freedom against the

\footnotetext{
4 Sartre (2003, p. 296).

5 Sartre (2003, p. 286).

${ }^{6}$ Sartre (2003, p. 283, 287).

7 Sartre (2003, p. 286).

8 Sartre (2003, p. 287, 294).

9 Sartre (2003, p. 286, 291).

${ }^{10}$ Sartre (2003, p. 289).

11 Sartre (2003, p. 294).
} 
Other, as in sadism, or submit my freedom to the Other, as in masochism, but I can never fully escape the dynamics of shame which sketch these two basic possibilities for intersubjective life. ${ }^{12}$

However, by proving the Other's freedom in this way, Sartre forecloses the possibility of substantially transforming shame or moving beyond its stalled dialectic. The pattern of oscillation between sadism and masochism remains bound to the moment of shame; self and Other remain stuck in the same scenario, merely exchanging positions in the same triangular schema. Even though Sartre recognizes the sense in which Others are not merely "added on" to a solitary subject, but rather affect the subject in its very being, nevertheless the way Sartre sets up the encounter with the Other suggests that one is first and foremost an absolutely free being-foritself and then becomes for-the-Other through a shame-inducing encounter. While Sartre's phenomenology of shame seems right to me, I am less convinced that this account of shame is an adequate starting-point for a phenomenology of social life. As one who is born to another, I am always already in relation to Others, even before I become aware of myself as a separate subject. There was never a time when I actually existed as a pure for-itself, untouched by the complicated burden of beingfor-Others. Even if shame does characterize our relation to Others who challenge our freedom, it tells us little about our relations with Others who nurture and support our freedom to the point where an experience of shame is even possible.

And yet, Sartre's insistence on the real presence of the Other and the crucial role that this presence plays in the concretization of my own self-relation, suggests that a more complicated reading is also possible. Insofar as it is structured by ontological shame, there is a certain dispossession at the heart of the subject, an extimate presence of the Other in the midst of my own intimate self-relation. The site of this extimate intimacy is the body. It is precisely by regarding me as a material presence, an object or being-in-itself, that the Other endows me with an outside, an objective body or Körper, which both belongs to me and escapes my grasp. "Thus the Other has not only revealed to me what I was; he has established me in a new type of being which can support new qualifications. This being was not in me potentially before the appearance of the Other, for it could not be found any place in the For-itself." 13 This suggests that the real presence of the Other has something to teach me, something that is not merely awakened in me but derives from the fact that I am not the only subject in the world. For Sartre, the lesson which the Other teaches me is shame; and the lesson of shame is that I have an outside that is vulnerable and exposed, a body that exceeds my own conscious experience. ${ }^{14}$ As we will see, Levinas also thinks that the Other has something to teach me, but for him, the lesson is ethical; the Other teaches me not only my exposure and the body it entails, but also the responsibility which emerges in the midst of this exposure.

For Sartre, the feeling of being caught in the gaze of the Other-whether or not this gaze can be traced to anyone concrete-alters the terms of my existence and complicates my relation to time. As being-for-itself, I exceed the present and the past

\footnotetext{
12 Sartre (2003, pp. 383-452).

13 Sartre (2003, p. 246, emphasis added).

14 Sartre (2003, p. 282).
} 
through an ek-static relation to possibility and to a future which is not yet. But as a being-for-Others, I am spatialized and temporalized as an object on the perceptual horizon of the Other. When the Other grasps me in terms of his own possibilities, he temporalizes himself as a being-in-the-world, but he also temporalizes me as part of his world; my own subjectivity acquires an objective dimension, a position within what Sartre calls "universal time." 15 Just as my embodied spatial presence acquires an outside through the gaze of the Other, "My presence, in so far as it is a present grasped by another as my present, has an outside." ${ }^{16}$ And just as the Other opens up a spatial "drain hole" in my world, so too does "physical time [flow] toward a pure and free temporalization which I am not."17

But for Levinas, the temporality of the encounter with an Other is more complicated; it is not merely the temporal equivalent of the spatial dynamics involved in seeing and being seen. If we develop Sartre's insight that one's own embodied selfrelation implies a reference to the real presence of the Other beyond Sartre's own framework of sadism and masochism, then we may arrive at a different account of the intertwining temporalities of self and Other, and even a different account of the social dynamics of shame. What if the freedom of the Other did not merely block my own freedom, turning me into an object? What if it did not block my ek-static relation to future possibilities, but rather gave me a new way of relating to the future which does not turn on possibility or the frustration of possibility, and which does not require me to be either a master or a slave? For this, we must turn to the work of Levinas.

\section{Shame as ethical provocation}

In a sense, all of Levinas' work could be read as a sustained meditation on ethical shame, understood as a feeling of remorse and responsibility for the suffering of others, whether or not I have done anything personally to cause this suffering. Levinas' challenge is to rethink responsibility unhinged from guilt, and even unhinged from action, in a way that vindicates bad conscience, not as a sign of Nietzschean ressentiment, but as a feeling of "being-put-in-question, but also put to the question, having to answer - the birth of language in responsibility." "18 For me, Levinas' approach to ethical shame resonates closely with Primo Levi's account, in The Drowned and the Saved, of:

the shame which the just man experiences when confronted by a crime committed by another, and he feels remorse because of its existence, because of its having been irrevocably introduced into the world of existing things, and because his will has proven nonexistent or feeble and was incapable of putting up a good defense. ${ }^{19}$

\footnotetext{
15 Sartre (2003, p. 291).

16 Sartre (2003, p. 291).

17 Sartre (2003, pp. 278-279, 291).

18 Levinas (1998a, p. 124).

${ }^{19}$ Levi (1988, pp. 72-73)
} 
Whether or not I have done something wrong, merely to exist is already-in principle, at least - to exist in the place of another, eating food that could have satisfied another's hunger, drinking water that could have meant the difference between her death and survival. The face of the Other calls into question my spontaneous freedom-my being-for-itself in the sense of naïve self-absorption — and commands me to answer for the violence that my existence might have done to others, with or without malicious intent. The provocation of the Other makes it impossible for me to deny my responsibility in good conscience, to ask, "What is Hecuba to me? Am I my brother's keeper?" ${ }^{20}$ Some readers have interpreted Levinas' vindication of bad conscience as a sign of masochistic submission to the Other. ${ }^{21}$ But I will argue that Levinas' approach does just the opposite: It shows how the sad passion of shame may be transformed into responsibility rather than ressentiment, and into a source of solidarity rather than perpetual struggle for domination. The key to understanding this transformation is Levinas' account of ethical temporality, in which the Other does not block my future but rather opens it up.

Levinas' explicit account of shame is limited to two main texts, On Escape and Totality and Infinity, as well as a few comments scattered throughout his work. ${ }^{22} \mathrm{His}$ first analysis of shame appears in On Escape (first published in 1935, eight years before Sartre's Being and Nothingness (1943)). Here, shame is introduced as the mood proper to ontological self-encumbrance, or what Levinas calls "enchainment": the feeling of having to be oneself, unable to escape one's own relation to being. ${ }^{23}$ What haunts Levinas in this early work is not the claim that the Other makes on me, but the burden of my own existence, the irremissibility of having-tobe, and the impossibility of escaping to an "otherwise than being" (although the later Levinas will locate this "otherwise" in a mode other than possibility). It's not that being is insufficient, or that it lacks something essential; rather, what Levinas finds oppressive about being is its fullness or plenitude. Not even death provides an exit from being, as Sartre also notes in his novel, Nausea, written three years after On Escape: "I dreamed vaguely of killing myself to wipe out at least one of these superfluous lives. But even my death would have been In the way. In the way my corpse, my blood on these stones, between these plants, at the back of this smiling garden... I was In the way for eternity." 24

And yet, the difference in approach between Levinas and Sartre is dramatic. ${ }^{25}$ While for Sartre, shame arises when my subjective freedom is challenged by an Other who regards me as an object and so condemns me to immanence, for Levinas,

\footnotetext{
${ }^{20}$ Levinas (1989, p. 170).

21 See for example, Wood (2005) and Žižek (2005).

22 Levinas (1998a, p. 169, 1998b, p. 90, 111, 195).

23 "In the identity of the I [moi], the identity of being reveals its nature as enchainment, for it appears in the form of suffering and invites us to escape" (2003, p. 55).

24 Sartre (1969, pp. 128-129). Compare Levinas' account of nausea (2003, pp. 66-68).

25 For a different analysis of the relation between Levinas and Sartre, which ultimately sides with a (poststructuralist reading of) Sartre, see Visker (1999, pp. 326-356). Visker also offers an intriguing account of shame as "the philosophical cornerstone on which Levinas' ethics rests" (1999, pp. 130-135). But, as will become apparent in the argument to follow, I disagree with Visker's claim that Levinas' thought, "in the final analysis, amounts to an ethicization of Sartre's dualism" (1999, p. 140).
} 
my own solitary relation to being already traps me in immanence. "What appears in shame is thus precisely the fact of being riveted to oneself, the radical impossibility of fleeing oneself to hide from oneself, the unalterably binding presence of the I to itself." ${ }^{26}$ At stake here is not the gaze of the Other, but rather the impersonality of being to which I am exposed without shelter or refuge. If the structure of shame is triangular here, it is a triangle in which the Other does not (yet) figure, a suffocating relation between me, myself and being:

It is therefore our intimacy, that is our presence to ourselves, that is shameful. It reveals not our nothingness but rather the totality of our existence. Nakedness is the need to excuse one's existence. Shame is, in the last analysis, an existence that seeks excuses. What shame discovers [découvre] is the being who uncovers himself [se découvre]. ${ }^{27}$

Levinas invokes the image of Charlie Chaplin in City Lights, who swallows a whistle that betrays his presence every time he breathes. Not only is the tramp unable to hide from others, but he is unable to hide from himself, or to let the brute fact of his bodily existence fade into the background.

In his commentary on On Escape, Jacques Rolland notes a remarkable consonance between the language Levinas uses to describe the ontological shame that rivets me to my own being, and the language he uses to describe anti-Semitism. In an essay from 1935, the same year as the publication of On Escape, Levinas writes:

Hitlerism is the greatest trial — an incomparable trial—-through which Judaism has had to pass... The pathetic destiny of being Jewish becomes a fatality. One can no longer flee it. The Jew is ineluctably riveted to his Judaism. ${ }^{28}$

To reduce someone to their ethnicity, race or religion-even if this aspect of their identity means something important to that person-is to chain them to their identity in a way that forecloses any future that could be otherwise, a future in which this or that aspect of one's identity might have a somewhat different meaning. It is this irremissible weight of a fate or destiny, without opening to the otherwise, that Levinas seeks to escape through his critique of both ontology and Hitlerism. While Levinas does not explicitly analyze the temporality of shame in On Escape, Rolland observes that shame feels like an endless prolongation of the instant, a "fracture in time... like the opening of a sort of present that seems no longer able to finish unless shame itself is lifted." 29 Like the insomnia of the il y a-the exposure to impersonal being which Levinas describes in Existence and Existents and Time and the Othershame extends interminably without interruption or escape route. The only path of escape is through a relation to the Other who opens a future that is not my own, beyond the horizon of my own being. ${ }^{30}$ This path is not yet marked in On Escape, but it is explored at length in Totality and Infinity, published 30 years later.

\footnotetext{
${ }^{26}$ Levinas (2003, p. 64, emphasis added).

27 Levinas (2003, p. 65).

28 Levinas (2003, p. 74). Cited by Rolland.

${ }^{29}$ Levinas (2003, p. 83).

30 See Levinas (1978, pp. 58-67) and (1987, pp. 48-51).
} 
In Totality and Infinity, shame no longer figures as a sign of ontological selfencumbrance but rather of ethical provocation by the Other. Ethical conscience is awakened in shame before an Other who is nakedly exposed to the violence of my own arbitrary, unjustified, and naively self-absorbed freedom. The Other awakens this conscience not by activating capacities which already lie dormant in me, but rather by putting my freedom in question and challenging me to justify this freedom, investing it as responsibility and political solidarity (or what Levinas calls "fraternity"). ${ }^{31}$ As for Sartre, the real presence of the Other introduces something new into my being; but instead of blocking my transcendence as a subject for-itself, for Levinas, the Other opens up a future beyond the projects and possibilities of a single subject. Levinas' way of describing this transcendence of the Other borrows from Descartes' idea of infinity, which also may have inspired Sartre's ontological proof for the existence of another subject. The figure of infinity describes the relation of consciousness to that which exceeds it, an infinity the idea of which could not have been created by consciousness alone, but which is nevertheless found within consciousness as a trace of that which produced it. It is a figure of the more in the less, of transcendence within immanence, infinity within the finite. For Levinas, the process of measuring oneself against the infinite demand of the Other "is accomplished as shame, where freedom discovers itself murderous in its very exercise. It is accomplished in shame where freedom is at the same time discovered in the consciousness of shame and is concealed in the shame itself." 32

This freedom, both revealed and put in question in shame before the Other, is not only the source of ethical reflection, but also of critical reflection as such, and so of knowledge and reason. ${ }^{33}$ The very meaning of these concepts is altered by ethical interrogation: reason is no longer to be found in a faculty of the individual subject, but in the practice of giving reasons to an Other who puts me in question; knowledge is no longer the essential correlation of consciousness to a world, but the offering of a world that was hitherto mine to an Other who commands me to generalize my singular experience, to put my sensible affects in common by using concepts. The Other's questioning face turns me back upon myself at a critical angle; it bends the intentionality of consciousness, which otherwise radiates out from itself in a movement of indefinite expansion, back upon itself and even beyond itself, to interrogate its own conditions. Again, a comparison with Sartre is instructive here: the Other does not merely produce a reflection of myself as I must appear from the outside, as an object for-the-Other, but rather provokes me to

\footnotetext{
31 I do not have space here to discuss the relationship between responsibility and fraternity in full detail; see Guenther (2006, pp. 77-84 and 147-55) for a discussion of fecundity, paternity and the relation between ethics and politics. For Levinas' brief discussion of fraternity, see Totality and Infinity, pp. 278-280. The most important passage in this section for my interpretation of fraternity as political solidarity is this: "The relation with the face in fraternity, where in his turn the Other appears in solidarity with all the others, constitutes the social order, the reference of every dialogue to the third party by which the $W e$-or the parti-encompasses the face to face opposition, opens the erotic upon a social life, all signifyingness and decency, which encompasses the structure of the family itself" (1969, p. 280).

32 Levinas (1969, p. 84).

33 "The freedom that can be ashamed of itself founds truth (and thus truth is not deduced from truth). The Other is not initially a fact, is not an obstacle, does not threaten me with death; he is desired in my shame“ (1969, pp. 83-84).
} 
respond, to become an interlocutor in a conversation which is more than a reciprocal exchange of words. In this conversation, I must answer in the first person, as myself; and yet, I am also drawn beyond the limits of myself by a command to respond which increases the more I answer it. In this sense, the ethical shame which the Other provokes in me does not make me feel stuck to myself; rather, it opens a way of getting un-stuck from my own suffocating relation to being. This way points beyond the subject, towards a being-for-the-Other to the point of substitution and even dying-for-the-Other, but it also points before the subject, to the conditions of possibility for my own freedom. We question ourselves, and ultimately we question being, because we have been put in question by an Other, because we have been called to justify ourselves to one whose vulnerability is exposed to the potential violence of our arbitrary freedom. Without this experience of being put in question by an Other, there is no motivation for critique, nothing to interrupt the spontaneity of the for-itself, no command to reflect on the conditions of one's own freedom. Critique begins in shame-if by shame we mean the experience of being turned back upon oneself by a feeling of ethical exposure to the face of an Other whose presence commands me to justify myself. Philosophy, the vocation of perpetual questioning, does not antecede this experience of being put in question by another, which marks the birth of the philosopher as an ethical subject and therefore also as a speculative theoretical subject. In this sense, conscience precedes consciousness, and ethics is first philosophy. ${ }^{34}$ Philosophy may be born in wonder, but wonder is born in shame.

The critical provocation of shame both highlights our freedom and conceals it by subordinating freedom to responsibility. But shame does not destroy freedom; it merely commands me to justify my freedom, and to invest it in ethical responsibility. ${ }^{35} \mathrm{~A}$ freedom invested is a freedom divested of its arbitrary spontaneity, and so made meaningful. What does it mean to "invest" one's freedom? I see this as a transformation of the existential concept of "commitment," where authentic freedom arises from a full engagement in the creation and active projection of values which make the world meaningful for oneself. While the commitment to collective values is not inconceivable for Sartre (hence his existentialist Marxism, for example), these values have meaning only insofar as each subject affirms them for him-or herself. The investment of freedom is different; it situates meaning not in subjective affirmation, but in critical response to an interlocutor who is perpetually putting me in question. Ultimately, for Levinas, freedom is invested — and so becomes meaningful-only in "Discourse and Desire, where the Other presents himself as an interlocutor, as him over

\footnotetext{
34 "If philosophy consists in knowing critically, that is, in seeking a foundation for its freedom, in justifying it, it begins with conscience, to which the other is presented as the Other, and where the movement of thematization is inverted" (1969, p. 86). The movement of shame is not from inside out, like intentionality, but from outside in, like sensibility, and like the questioning that provokes critique.

35 "Existence is not in reality condemned to freedom, but is invested as freedom. Freedom is not bare" (1969, p. 84). See also Totality and Infinity p. 88, where this investment of freedom is called the foundation of reason, and Totality and Infinity pp. 302-304, where Levinas contrasts this investment of a freedom which, prior to investment, "appear[s] to itself as a shame" with Sartre's account of "the fall of my freedom" (1969, p. 303).
} 
whom I cannot have power, whom I cannot kill... where, qua I, I am not innocent spontaneity but usurper and murderer." ${ }^{36}$ At the very moment I am commanded not to murder, I appear to myself as both a murderer and a responsible subject. At the very moment my freedom is put in question, I discover both its violence and its power to intercede for others. Shame is Levinas' name for the radical ambivalence of this moment as a pivot-point between murder and ethics, between violence and goodness. Shame itself is neither good nor evil, but is rather the feeling of inescapable exposure to these alternatives posed by the face of the Other. It is a chance for both the ethical subject to emerge in freedom invested as responsibility, and for the murderer to ask, "Am I my brother's keeper?"

This account of shame as ethical provocation seems distant from Levinas' earlier analysis of shame from the perspective of one who is both riveted to an identity and exposed without a chance to escape. But in both contexts, shame points to an ambivalent moment, an instant that refuses to pass, a problem that remains irresolvable within its own terms. I can neither be what I am nor refuse to be. As embodied existents, weighed down by our own relation to being, we must wrestle with this ambivalence; and as subjects who encounter Others face-to-face, we find that the stakes of this ambivalence are ethical as well as ontological. The investment of being for-the-other promises to transform the shame of existence, such that the suffocating weight of existence becomes a material basis for feeding the other, a site from which to offer hospitality, a ballast for responsibility.

This interpretation works fairly well as long as we assume the perspective of a subject whose freedom and power put others at risk. But where does it leave the Jew who is "riveted to his Judaism" by Hitlerism, or even the tramp who is betrayed not only by the comic device of a whistle, but by the clothing and gestures that announce his poverty beyond what he may choose to assert or deny? For Levinas, ethical responsibility is not correlated to social power; the tramp as well as the king is commanded by the face of the Other to invest his freedom ethically. But the shame of being poor in a capitalist society, or the shame of being Jewish under Hitlerism, is not fully captured by Levinas' ethical account of shame, and without a more political account of shame, it risks being assimilated to the ontological shame of existence without remainder. For this political phenomenology of shame, we need to look beyond Levinas, to the work of Simone de Beauvoir.

\section{Shame as political provocation}

In The Second Sex, Beauvoir describes the process of becoming a woman as an extended lesson in shame. The girl who, like her brother, relates to her body initially as "the radiation of a subjectivity, the instrument that brings about the comprehension of the world," ${ }^{37}$ soon learns that her body is not her own, but an instrument and a value for others. The mechanism of this feminine pedagogy is the gaze of others who respond to the girl's developing sexuality in ways that both reduce her to

\footnotetext{
36 Levinas (1969, p. 84).

37 Beauvoir (2010, p. 283).
} 
her body and alienate her from it, leaving her nowhere to hide but also nowhere to be. Beauvoir recounts the stories of women responding to the shock of this interpellation:

A man, sniggering, made a comment about my fat calves. The next day my mother made me wear stockings and lengthen my skirt, but I will never forget the shock I suddenly felt in seeing myself seen. ${ }^{38}$

For two years I wore capes to hide my chest, I was so ashamed of it. ${ }^{39}$

The structure of shame that Sartre and the early Levinas analyze as a general ontological predicament, emerges in The Second Sex as the specifically feminine ordeal of being bound to a body that is both alien and one's own, both exposed to the gaze of others and inescapable. ${ }^{40}$ While the boy is able to escape his body without alienation, the girl's body escapes her, like a drainhole opened up in what she might have otherwise assumed was her autonomous existence:

The little girl feels that her body is escaping her, that it is no longer the clear expression of her individuality; it becomes foreign to her; and at the same moment, she is grasped by others as a thing: on the street, eyes follow her, her body is subject to comments; she would like to become invisible; she is afraid of becoming flesh and afraid to show her flesh. ${ }^{41}$

Like the Jew in Levinas' early essays on Hitlerism, the woman is riveted to her own body, not merely by the ontological structure of intersubjectivity, but by the social and political structure of a gender oppression that exposes her to the gaze of others as a sexual object, while blocking her emergence as a fellow subject with legitimate desires of her own.

For Beauvoir, shame is lived in the body; but the body is already a social and political interface, a way of being rooted in the world and exposed to the gaze of others. With the growth of breasts and pubic hair and the onset of her menstrual cycle, the girl's body seems to betray her; it leaks and bulges and sprouts in all sorts of disconcerting ways. But these bodily transformations are not in themselves the source of the girl's shame; after all, the boy's body undergoes changes, too. ${ }^{42}$ What is missing for the girl is a narrative that could help her make sense of these changes and to claim them as her own rather than as signs of "a dependence that dooms her to man, child and tomb." ${ }^{43}$ While the boy is encouraged to identify with his penisa part of his own body - and to relate to it as "a little person who is both himself and other than himself," ${ }^{44}$ Beauvoir argues that the girl "cannot incarnate herself in any

\footnotetext{
38 Beauvoir (2010, p. 321).

39 Beauvoir (2010, p. 321).

40 As Beauvoir puts it: "woman is her body as man is his, but her body is something other than her" (2010, p. 41).

41 Beauvoir (2010, p. 321).

42 Beauvoir (2010, p. 329).

43 Beauvoir (2010, p. 321).

44 Beauvoir (2010, p. 287).
} 
part of her own body." 45 Instead, she is encouraged to identify with a doll, a passive plaything whose value lies in being looked at and manipulated by others. There may be pleasure to be found in being treated like a "living doll," 46 and Beauvoir acknowledges women's complicity in seeking such pleasures; but these pleasures do not offer a solution to the problem of feminine shame. Blocked from identifying with her own body as a site of ambiguous transcendence, and interpellated as an object for others, the girl "literally... no longer sees her own body." ${ }^{77}$ She sees only her reflection in the gaze of others: a reflection she can neither escape nor identify with. The lesson of femininity has been learned:

[S]he already knew her sex condemned her to a mutilated and frozen existence; she now discovers it in the form of an impure illness and obscure crime... She makes her way toward the future wounded, shamed, worried, and guilty. ${ }^{48}$

What is a woman to do with this shame? And how might she respond to what Beauvoir describes as the shame of femininity without turning femininity itself, and her own complicity with it, into a further source of shame? Beauvoir's analysis makes it clear that the resistance of a single individual is not enough to transform the norms of femininity and to open the future of women beyond a "mutilated and frozen existence." And yet, part of the problem she diagnoses is the isolation of women by the shame of exposure to both men's and women's judgment. It is not just the gaze of men that a woman has to worry about, but also the gaze of mothers, aunts, sisters, schoolteachers, neighbors and friends. However, the very exposure that opens the problem of shame also makes possible the only adequate response: solidarity with others who both hold open the future for me and-for that very reason-are capable of blocking it. Shame's ambivalence bears the possibility of both abjection and solidarity-both an indissoluble connection to others and the constant risk that this indissoluble connection can be refused, manipulated and exploited. In this sense, shame presupposes a relationality that is more fundamental than individuated subjectivity. If we were not exposed to others all the way down, in a way that is constitutive of who we are, then we could not be undermined by shame. It is because others matter to us in ways that exceed individual choice or control that our relationality can be exploited in shame, but also invested as ethical responsibility and political solidarity.

This productive side of shame's ambivalence becomes evident in Beauvoir's memoir, Force of Circumstance, where she reflects on her own shame of complicity in French colonial domination:

I'm French. The words scalded my throat like an admission of a hideous deformity. For millions of men and women, old men and children, I was just one of the people who were torturing them, machine-gunning them, slashing

\footnotetext{
45 Beauvoir (2010, p. 293).

46 Beauvoir (2010, p. 295).

47 Beauvoir (2010, p. 292).

48 Beauvoir (2010, p. 340).
} 
their throats, starving them; I deserved their hatred because I could still sleep, enjoy a walk or a book. ${ }^{49}$

Seeing herself through the (imagined) gaze of an Algerian survivor of torture, Beauvoir feels her identity as a French woman as a shameful source of privilege. Not only is this privilege an arbitrary and unjustified aspect of her factical existence, rather than something she has freely chosen, but it is also part of a machinery of colonial violence to which Beauvoir is morally and politically opposed, but from which she nevertheless profits:

I know that I am a profiteer, and that I am one primarily because of the education I received and the possibilities it opened up for me. I exploit no one directly; but the people who buy my books are all beneficiaries of an economy founded upon exploitation. I am an accomplice of the privileged classes and compromised by this connection; that is the reason why living through the Algerian war was like experiencing a personal tragedy. When one lives in an unjust world there is no use hoping by some means to purify oneself of that injustice; the only solution would be to change the whole world, and I don't have the power. ${ }^{50}$

Beauvoir claims, perhaps too modestly, that she does not have the power to change the world; and yet her response to the Algerian war provides an instructive example of how the profiteer's shame may be invested politically and redeployedto some extent, at least-against her own inherited privilege. Beauvoir compares the Algerian war to a "personal tragedy," and some readers may bristle at what seems, and may very well be, a narcissistic way of referring to a war in which up to a million Algerians died and countless people were tortured, leaving behind a legacy of violence and conflict that continues to this day. One might wonder if the profiteer is more outraged at the violence itself, or at the unfairness of being implicated in this violence without having chosen or consented to it. But in the moment when Beauvoir acknowledges herself as a profiteer, and acknowledges the impossibility of purifying herself of the injustice which has been committed in her name-without her consent, but nevertheless to her benefit - she attests to a collective responsibility that goes beyond the alternatives of individual guilt or innocence. The crime of colonial aggression forms part of Beauvoir's facticity as a French citizen, part of the ambiguity with which her ethical life must come to terms, but which it can never definitively resolve. The Algerian War is for her a personal tragedy because it makes her an accomplice to crimes that she vigorously opposes; but it is not only a personal tragedy, and the political potential of shame lies in the possibility of investing this personal affect in solidarity and collective responsibility with others.

In response to her shame as a French profiteer of colonialism, Beauvoir joined forces with the Tunisian-born lawyer, Gisèle Halimi, to advocate for Djamila Boupacha, an Algerian prisoner of war who had been tortured and raped by French military forces. In 1960, she wrote an article in Le Monde, "In Defense of Djamila

\footnotetext{
49 Beauvoir (1994, p. 106).

50 Beauvoir (1994, pp. 374-375).
} 
Boupacha," and founded a political action committee to petition for Boupacha's release, the protection of her family, and the prosecution of her torturers. Together with Halimi, she published a book on Boupacha's case, sharing legal responsibility with her co-author for the retributive violence that the book might unleash. ${ }^{51}$ Beauvoir's political action was not free from ambivalence; Boupacha remained in French prison until the Evian agreement of March 1962, which granted amnesty to Algerian prisoners but also to French officials accused of abusing their power. Boupacha returned to Algeria after the trial, apparently brought there by the FLN against her will. Later, Halimi accused Beauvoir of using Boupacha's case as a way of assuaging her own feelings of colonial shame, without entering into a genuine relationship with herself or Boupacha. In Halimi's words: "I expected a sister-inarms" but "I discovered more and more an entomologist... For her, Djamila was one victim among thousands, a useful 'case' in the battle against torture and war." 52

There is much to learn from this example about the dynamics of postcolonial politics and the viability of a politics motivated by the shame of privilege. ${ }^{53} \mathrm{My}$ concern here is not to judge the success or sincerity of Beauvoir's interventions, but to reflect on the irresolvable ambivalence of shame as a phenomenological structure with ontological, ethical and political implications. For Sartre and Levinas, as well as for Beauvoir, shame attests to an inescapable relationality that is both painful and productive; it marks an exposure to others that both constitutes the self as a being-forOthers and also threatens to undermine the self's integrity through shameful humiliation, but also through shameful privilege. Shame is a way of getting stuck in an impossible moment that I can neither inhabit nor flee, a time that goes nowhere and yet, precisely because of this ambivalence, still retains a transformative potential. In this sense, shame is less an attribute of the self than an affective articulation of the hinge between self and other. We see this most clearly in Levinas, where the shame of ethical provocation opens the possibility of both murder and responsibility; but it is also the case for Sartre, where shame inaugurates the oscillation of sadism and masochism without yet belonging to either. For Beauvoir, shame arises in response to both feminine oppression and French privilege; her analysis in particular shows that the provocation of shame has both revolutionary and reactionary potential, but that it is rarely, if ever free from ambivalence. To the extent that Beauvoir's response to either the shame of oppression or the shame of privilege succeeds in moving beyond the stalled moment of individual shame, it is in joining with others across intersecting lines of power to co-create a collective future.

My aim in bringing these thinkers together has been to articulate the ontological, ethical and political ambivalence of shame as the feeling that most eloquently expresses our embodied entanglement with others, in its potential for both violence and solidarity, and to connect this ambivalent potential to the temporality of social life. In a world where social power is unevenly distributed along axes of race, class, gender, sexuality, nationality, and so many other ways of cutting up identity, there

\footnotetext{
51 Beauvoir and Halimi (1962).

52 Halimi (1990, p. 301; cited Murphy 1995, p. 283). See Kruks (2005) for a detailed account of this conflict, and a plausible defense of Beuavoir's actions.

53 See, for example, Murphy (1995), Kruks (2005), Caputi (2006).
} 
may be no social position free from the stickiness of shame. For many of us, these axes intersect in ways that privilege us in some respects and oppress us in others, entangling us in multiple and conflicting forms of shame. There may be no clean way to resolve the ambivalent dynamics of shame; but this does not mean that we are doomed to remain stuck in the repetition of the same. Rather, it suggests that the politics of solidarity and collective responsibility is more than just our ethical and political obligation; it is our future. We only have a future, both personally and collectively, if we respond to the ontological, ethical and political provocations of shame in a way that shifts the focal point from preserving our own self-relationour place in the world, what Levinas might call "my place in the sun" - towards a responsible relation with others. This is not to say that everyone must advocate for everything at all times, but that there is no time-no future for the struggle against oppression-without an investment of our freedom and our vulnerability in collective responsibility and political solidarity with others. ${ }^{54}$

The ambivalence of shame attests to the irreducibility of our exposure to others, both as the site of relationality and ethical responsibility, and as the site of its exploitation through oppression. The opening of ethics is not simple, but dangerous; the same exposure that makes responsibility possible also makes murder possible. But this also means that the impulse to murder and oppress-to deny the other an open future-remains bound to the very ethical command that it violates. I can murder the other, but I cannot silence the ethical command of the other; I can be complicit in the political exploitation of myself or others, but I cannot foreclose the possibility of solidarity. And as Beauvoir's own political action shows, even when I do commit myself in solidarity to responsibility for others, I cannot guarantee that my own motives will be pure of self-interest. This ambivalence does not foreclose the provocations that open and re-open own actions to critical interrogation; it presupposes them. Shame would not be possible if others did not matter to us; and because others matter, oppression is not the last word on shame but only one of its ambivalent possibilities.

\section{References}

Beauvoir, Simone de. 1994. Hard times: Force of circumstance, vol. II (trans: Peter Green). New York: Da Capo Press.

Beauvoir, Simone de. 2010. The second sex (trans: Constance Borde and Sheila Malovany-Chevallier). New York: Alfred A. Knopf.

Beauvoir, Simone de and Gisele Halimi. 1962. Djamila Boupacha (trans: Peter Green). Andre Deutsch and Weidenfeld and Nikolson.

\footnotetext{
54 The investment of collective shame as collective responsibility does not undermine projects to hold those who are guilty of breaking the law criminally responsible for their actions. My point is rather that the meaning of responsibility is not exhausted by criminal responsibility, and not exclusively measured by law. As Levinas puts it in Totality and Infinity: "Justice summons me to go beyond the straight line of justice, and henceforth nothing can mark the end of this march; behind the straight line of the law the land of goodness extends infinite and unexplored, necessitating all the resources of a singular presence. I am therefore necessary for justice, as responsible beyond every limit fixed by an objective law" (1969, p 245). It is precisely this "beyond" that is sketched out by shame, in distinction from guilt.
} 
Bond Stockton, Kathryn. 2006. Beautiful Bottom, Beautiful Shame: Where "Black" Meets "Queer". Durham and London: Duke UP.

Calhoun, Cheshire. 2004. An apology for moral shame. The Journal of Political Philosophy 12(2): 127-146.

Caputi, Mary. 2006. Beauvoir and the case of Djamila Boupacha. In Simone de Beauvoir's political thinking, ed. Lori Jo Marso, and Patricia Moynagh. Urbana and Chicago: University of Illinois Press.

DuBois, W.E.B. 1995. On Being Ashamed of Oneself. In W. E. B. DuBois: A Reader, ed. David Levering Lewis. New York: Henry Holt, 76-81.

Fanon, Frantz. 1968. Black Skin, White Masks, (trans: Charles Lam Markmann). New York: Grove Press.

Felski, Rita. 2000. Nothing to Declare: Identity, Shame and the Lower Middle Class in Doing Time: Feminist Theory and Postmodern Culture. New York: NYU Press.

Guenther, Lisa. 2006. The gift of the other: Levinas and the politics of reproduction. Albany, NY: SUNY Press.

Halimi, Gisele. 1990. Milk for the Orange Tree (trans: Dorothy S. Blair). London: Quartet.

Kafka, Franz. 2000. The trial (trans: Idris Parry). Harmondsworth: Penguin.

Kruks, Sonia. 2005. Simone de Beauvoir and the politics of privilege. Hypatia 20(1): 178-205.

Levi, Primo. 1988. The drowned and the saved (trans: Raymond Rosenthal). New York: Summit Books.

Levinas, Emmanuel. 1969. Totality and infinity: An essay on exteriority (trans: Alphonso Lingis). Pittsburgh: Duquesne University Press.

Levinas, Emmanuel. 1978. Existence and existents (trans: Alphonso Lingis). The Hague: Martinus Nijhoff.

Levinas, Emmanuel. 1987. Time and the other (trans: Richard A. Cohen). Pittsburgh: Duquesne University Press.

Levinas, Emmanuel. 1989. In The Levinas reader, ed. Seán Hand. (trans: Seán Hand and Michael Temple). Oxford: Blackwell.

Levinas, Emmanuel. 1998a. Entre Nous: Thinking-of-the-other (trans: Michael B. Smith and Barbara Harshav). New York: Columbia University Press.

Levinas, Emmanuel. 1998b. Otherwise than being, or beyond essence (trans: Alphonso Lingis). Pittsburgh: Duquesne University Press.

Levinas, Emmanuel. 2003. Intro and annotation. In On escape, ed. Jacques Rolland. (trans: Bettina Bergo). Stanford, CA: Stanford University Press.

Murphy, Julien. 1995. Beauvoir and the Algerian war. In Feminist interpretations of Simone de Beauvoir, ed. A. Margaret. Pennsylvania State University Press: University Park.

Nussbaum, Martha. 2004. Hiding from humanity: Shame, disgust, and the law. Princeton, N.J.: Princeton University Press.

Probyn, Elspeth. 2005. Blush: Faces of Shame. Sydney: UNSW Press.

Sartre, Jean-Paul. 1969. Nausea (trans: Lloyd Alexander, Hayden Carruth). New York: New Directions Publishing.

Sartre, Jean-Paul. 2003. Being and nothingness (trans: Hazel Barnes). London and New York: Routledge.

Sedgwick, Eve Kosofsky. 2003. Touching feeling: Affect, pedagogy, performativity. Durham and London: Duke UP.

Shotwell, Alexis. 2007. Shame in alterities: Adrian Piper, intersubjectivity, and the racial formation of identity. In The shock of the other: Situating alerities, ed. Silke Horstkotte, and Esther Peeren, 127-136. Amsterdam and New York: Rodopi.

Skeggs, Beverley. 1997. Formations of Class and Gender: Becoming Respectable. London: Sage.

Tarnopolsky, Christina. 2010. Prudes, perverts, and tyrants: Plato's Gorgias and the politics of shame. Princeton, NJ: Princeton UP.

Visker, Rudi. 1999. Truth and singularity: Taking foucault into phenomenology. Dordrecht, Boston and London: Kluwer.

Warner, Michael. 1999. The trouble with normal: Sex, politics and the ethics of queer life. Cambridge, MA: Harvard University Press.

Wood, David. 2005. Some questions for my Levinasian friends. In Addressing Levinas, ed. Eric Sean Nelson, Antje Kapust, and Kent Still. Evanston: Northwestern University Press.

Žižek, Slavoj. 2005. Neighbors and other monsters: A plea for ethical violence. In The neighbor: Three inquiries in political theology, ed. Slavoj Žižek, Eric L. Santner, and Kenneth Reinhard, 134-190. Chicago: University of Chicago Press. 